\title{
33. The Great Kwantô Earthquake of September 1, 1923, and the Geotectonic of the Meizoseismic Area.
}

By Hisakatsu YABE, M.I.A.

(Comm. March 12, 1930.)

In a paper of 1925, I have given a brief account of the major geotectonic divisions of the Kwantô region, with the geological history of each division and the relation of one to another. All the geological data then accumulated are suggestive of something like the causal relationship existing between the Fossa Magna and the great Kwantô earthquake of September 1, 1923.')

Results subsequently obtained by field observations and laboratory studies of the collaborators of the Institute of Geology and Palaeontology, Sendai, led me to a further development of my consideration on this subject, as outlined below.

1. Hitherto we found a formidable difficulty in deciphering the structural relation of the peninsulas of Bôsô and Miura; Miura Peninsula is a miniature copy of the Bôsô, both having geological formations, structural elements and morphological features in common, though the former peninsula has each of the tectonic units much reduced in height and breadth relative to the corresponding one of the latter. This reduction of structural units in height and breadth on the Miura Peninsula is so considerable in amount as to make the assumption incredible that the Bôsô and Miura Peninsulas once formed a single landmass of which one became separated from the other by later corruption of the Uraga Channel or by the lateral shifting, or both processes combined, although the fact is well familiar to us that certain elements narrow to a considerable amount from the eastern coast of the Bôsô Peninsula towards its western coast or the side nearer to the Miura Peninsula.

It seems to me that the Miura Peninsula was originally elongated north-south nearly as much as the Bôsô, the two being once actually continuous and forming a horst; later, however, the former peninsula has more shortened from south to north than the latter, thereby all the tectonic units of $\mathrm{E}-\mathrm{W}$ extension telescoping one another successively by underthrust and reducing in breadth and height.

1) H. Yabe and R. Aoki: The Great Kwantô Earthquake of September 1, 1923, Geologically Considered. Ann. Rep. Saitọ Gratitude Foundation, No. 1, 1926. 
2. The ancient horst of the Bôsô and Miura Peninsulas had its northern border of approximately $\mathrm{E}-\mathrm{W}$ trend, which almost coincides with the present southern limit of the distribution of the Narita Series, and the boundary can be taken as the base of the two peninsulas. While the base of the two peninsulas lies on a line of $\mathrm{E}-\mathrm{W}$ trend, the southern extremity of them lies on a line of NW-SE trend and hence diagonal to the former. This NW-SE lines is close and parallel to the deepest bottom, of linear extension, of the present Bay of Sagami, the line on which the maximum depression has been sounded after the great Kwanto earthquake, and the northeastern border of the Fossa Magna. It runs also along the hypothesical Itoigawa-Suntô Line of the Middle Tertiary origin."

This ancient horst once extended beyond the Ôiso block farther westnorthwestwards to the Ashigara district, north of the volcano Hakone, where conglomerate and sandstone of Younger Neogene Ashigara Beds thrust under the older Misaka breccia with Nephrolepidina limestone lenses of the Burdigalian stage, along a line of $\mathrm{E}-\mathrm{W}$ trend passing some $2 \mathrm{~km}$. north of the Yamakita station on the TokyoShimonoseki railway; this upthrust of the Misaka Series or the downthrust of the Ashigara Beds, first recorded some 25 years ago by the late Tetsunosuke Katô, ${ }^{2}{ }^{2}$ is very significant one. On one side, this line is almost parallel to another line of the same nature, lying $25 \mathrm{~km}$. farther north and marking the boundary between the younger Neogene deposits along the northern border of the Tanzawa Mountainland and the older rocks of the Kwantô Mountainland proper. On the other side, Kanôsan ridge of the Bôsô Peninsula is situated almost on the eastern prolongation of the Ashigara thrust line; the Kanôsan ridge, with its gentle northern slope subparallel to the stratification plane of the Pleistocene Narita Series and showing back of all the strata on the upper half of its steep southern side, can not be a simple cuesta as it first appears. We have good reason to take the ridge as the edge of the land upthrusted from the north or, in reverse, standing high above the underthrusted mass from the south. On the Bôsô Peninsula, several other thrusts of the similar nature and trend are expected to exist north and south of the Kanôsan ridge; on the Miura Peninsula, principal dislocations have approximately WNW-ESE trend, hence slightly deviating from the average trend of those in the Bôsô,

1) H. Yabe: The Itsukaichi-Kawakami Line (in Japanese). Jour. Geogr. Tôkyô, XXXVII, 1925. Larger Geotectonic of the Island Arc. of Japan Proper. Proc. 5 (1929), 465.

2) T. Katô: Geological Study of the Environs of Yamakita, Province of Sagami (in Japanese). Geol. Surv, Rep., No. 18, 1910. 
and are believed generally to be of the same nature with the corresponding ones of the latter peninsula.

There is another series of geological evidences speaking for the over- or underthrusting of strata in the Bôsô Peninsula. We have there abundant illustrious examples of what we call the intraformational disturbance-including all possible kinds of contortion, fracturing, sliding etc.-which we are hitherto accustomed in interpreting mostly as due to submarine sliding of new sediments under the partial solidification and sometimes to the downward sliding of overlying bed on the underlying one after the consolidation of rocks. A palaeogeographical study shows that a land existed on south of the area of deposition of the marine sediments of the Narita Series and consisted monoclinal strata of the Upper Miura Series with the NW dip; the intraformational disturbance being frequent in the Upper Miura and Narita Series, the sliding in either case must have taken place by northward sliding of the new sediments or more or less consolidated strata ; many facts, however, do not seem to satisfy this condition and a moment contemplation makes this explanation of sliding practically inapplicable for the actual cases in the present district, for (1) the intraformational disturbance of strata frequently accompanies faults larger and more significant than "minor faults," and (2) the contorted layers show frequently the feature pointing to the northward underthrusting of the lower bed or the southward overthrusting of the upper bed, contrary to our expectation. In my opinion, these intraformational disturbances seem to due to the over- or upthrusting of the northerly lying mass against the southern one or under- or downthrusting of the southerly lying mass against the northern one; owing to the rather loose nature of the material there prevails and probably also to the particular mode of movement, the movement has not given rise to any clean cut thrust plane of a considerable extension and was resolved into the intraformational disturbances taken place at innumerable points in certain incompetent rock layers.

Most probably the major thrust planes are quite low-angled in the deeper part and become steeper and divided into a number of smaller ones near the land surface. If such process went on repeatedly in a long range of geological time, covering the latest Tertiary and postTertiary, then the deeper or low-angled portion of the older thrust plane may be expected to leave its trace in intraformational disturbances in the strata with a gentle dip, while the younger thrust planes become known only of their upper or steeper portion, somewhat like the tilted edges of strata. Under this conception, the so-called 
geological blocks as maintained by the late Prof. N. Yamasaki and others, including myself, need future revision. By the way it will be noted that the rocks of the Older Miura Series of the Bôsô Peninsula show minor faults mostly belonging to the category of thrust or reversed fault.

3. The results of an accurate leveling of the meizoseismic area are in several points in disharmony with the block structure of the Bôsô Peninsula and adjacent land in the previous sense; this seems to imply the untenability of our early conception of the geotectonic of the region. On the other hand, the assumption here formulated conforms rather well, if not quite accurately, with the results of leveling and also with the result of Prof. T. Terada and N. Miyabe's study of the strain ellipse on the data of re-triangulation. ${ }^{1)}$ The latter shows that there is a distinct boundary of $\mathrm{E}-\mathrm{W}$ extension roughly coinciding with the Ashigara thrust and the assumed eastern prolongation of it, between the southern area in which the maximum contraction has taken place along the $\mathrm{N}-\mathrm{S}$ axis, locally with a slight deviation to $\mathrm{E}$ or $\mathrm{W}$, and the northern in which the maximum elongation has taken place along the N-S axis in general, sometimes with notable local deviation to $\mathrm{E}$ or $\mathrm{W}$. The displacement observed after the great earthquake seems in a whole to be in harmony with the crustal disturbances repeated in the latest geological ages.

4. All the facts cited above may easily be explained on the assumption that there exists a rigid body in the position of the Fossa Magna-superficially occupied by volcanic ejecta from the volcanoes of the Fuji Chain, including Hakone and Oshima, and with the boundary plane of NW-SE trend, and that pressure applied from north to that part of the earth's crust lying to the north of this rigid body was released by the repeated telescoping movement of all the tectonic segments of the region, that is to say by UNDERTHRUSTING of a southern one to the next northern; owing to the diagonal position of the rigid body, the shortening of the tectonic segments in north-south direction is intensified from east to west. The origin of the tectonic segments themselves is certainly due to the same cause.")

1) T. Terada and N. Miyake: Crustal Disturbance in Kwantô Districts. Proc. $6(1930), 49$.

2) I can not conclude this advanced summary without acknowledgment of the debt that I owe to the collaborators in the Institute of Geology and Palaeontology, Tohoku Imperial University, and in particular to Messrs. R. Aoki, M. Yoshii, S. Shimizu, S. Nomura, F. Ueda and R. Tayama. I take also this opportunity of offering my thanks to the authorities of the Saito Gratitude Foundation for the pecuniary support given to this research. 